\title{
In vitro assessment of the genotoxic and cytotoxic effects of boiled juice (tucupi) from Manihot esculenta Crantz roots
}

\author{
L.A. Cunha ${ }^{1}$, T.C. Mota ${ }^{1}$, P.C.S. Cardoso ${ }^{1}$, D.D.F.Á. Alcântara ${ }^{1}$, \\ R.M.R. Burbano ${ }^{1}$, A.C. Guimarães ${ }^{1}$, A.S. Khayat ${ }^{1}$, C.A.M. Rocha ${ }^{2}$ and \\ M.O. Bahia ${ }^{1}$
}

${ }^{1}$ Laboratório de Citogenética Humana, Instituto de Ciências Biológicas, Universidade Federal do Pará, Belém, PA, Brasil

${ }^{2}$ Coordenação de Recursos Pesqueiros e Agronegócio, Instituto Federal de Educação, Ciência e Tecnologia do Pará, Belém, PA, Brasil

Corresponding authors: L.A. Cunha / C.A.M. Rocha

E-mail: cunhala.bio@gmail.com / carlos.rocha@ifpa.edu.br

Genet. Mol. Res. 15 (4): gmr.15048825

Received May 19, 2016

Accepted June 29, 2016

Published October 5, 2016

DOI http://dx.doi.org/10.4238/gmr.15048825

Copyright (C) 2016 The Authors. This is an open-access article distributed under the terms of the Creative Commons Attribution ShareAlike (CC BY-SA) 4.0 License.

ABSTRACT. The population of Pará (a state in Brazil) has a very
characteristic food culture, as a majority of the carbohydrates
consumed are obtained from cassava (Manihot esculenta Crantz)
derivatives. Tucupi is the boiled juice of cassava roots that plays a
major role in the culinary footprint of Pará. Before boiling, this juice
is known as manipueira and contains linamarin, a toxic glycoside
that can decompose to hydrogen cyanide. In this study, the cytotoxic
and genotoxic effects of tucupi on cultured human lymphocytes were
assessed using the comet assay and detection of apoptosis and necrosis
by differential fluorescent staining with acridine orange-ethidium
bromide. Tucupi concentrations (v/v) were determined using the

Genetics and Molecular Research 15 (4): gmr.15048825 
methylthiazole tetrazolium biochemical test. Concentrations of tucupi that presented no genotoxic effects $(2,4,8$, and $16 \%)$ were used in our experiments. The results showed that under our study conditions, tucupi exerted no genotoxic effects; however, cytotoxic effects were observed with cell death mainly induced by necrosis. These effects may be related to the presence of hydrogen cyanide in the juice.

Key words: Manihot esculenta; Tucupi; Cytotoxicity; Genotoxicity; Cultured lymphocytes

\section{INTRODUCTION}

The population of Pará (a state in Northern Brazil) has a very characteristic food culture; for example, this population consumes a high quantity of salt as well as carbohydrates from cassava (Manihot esculenta; Euphorbiaceae) (Simão 2002; Resende et al., 2006; Chisté et al., 2007; Li et al., 2010). M. esculenta is an important source of energy for millions of people in tropical and subtropical countries (FAO, 1995; Gomes and Nassar, 2013). The roots of $M$. esculenta contain approximately $80 \%$ starch and are of major nutritional end commercial value. In addition to its importance as food, cassava also has an important socioeconomic role because of commercialization of its culinary derivatives, such as farinha, goma, and tucupi, which are available at markets and supermarkets in several localities in Northern Brazil (Rosário and Oliveira, 2010).

Tucupi is the boiled juice from cassava roots, which is obtained by hand by decanting the liquid removed from the peeled, grated, and squeezed cassava root; tucupi is widely used in the culinary culture of Pará (Rosário and Oliveira, 2010). Studies on the composition of tucupi are rare. The juice is called manipueira before boiling, and is rich in protein, carbohydrates, and various secondary metabolites (Magalhães et al., 2000). It contains linamarin, a toxic glycoside carcinogen that can release hydrocyanic acid (HCN) (Ponte, 1999). Cyanohydrin an intermediate compound, is produced by the catabolism of linamarin by linamarase. Cyanohydrin decomposes spontaneously or by the action of hydroxynitrile lyase, producing hydrogen cyanide or hydrocyanic acid (Magalhães et al., 2000; Idibie et al., 2007).

Because of the presence of hydrocyanic acid, manipueira must be boiled to ensure pronounced hydrolysis of the cyanogenic compounds with subsequent volatilization of HCN, and thereby rendering it fit for consumption as tucupi (Chisté et al., 2007; Rosário and Oliveira, 2010).

The presence of plant-based natural products in food is associated with the culture of a population and an analysis of the possible toxic effects of these products is important for the maintenance of good health. Among such effects are the genotoxic effects that take into account the vulnerability of the genetic material (DNA) to chemical, physical, or biological damage imposed by the environment (Ferreira, 2004). As none of the studies has been able to assess the effects of tucupi at the cellular level, the aim of this study was to evaluate the in vitro cytotoxicity and genotoxicity of this compound in human lymphocytes. According to Galloway et al. (2011), in vitro tests conducted with precision are important to reduce the need for further in vivo testing in the analysis of such parameters.

Genetics and Molecular Research 15 (4): gmr.15048825 


\section{MATERIAL AND METHODS}

\section{Tucupi sample collection}

Handmade tucupi was obtained from a cassava plantation in the city of Curuçá in Pará, Brazil. The cassava roots were grated and squeezed and the liquid obtained was decanted. The decanted supernatant was boiled for 20 minutes without adding any other component. The boiled juice was filtered for use in subsequent tests.

\section{Lymphocyte cell culture}

Blood samples $(20 \mathrm{~mL})$ were obtained by venipuncture from three healthy 22 -to-35 year old nonsmokers (two females and one male) with no recent history of exposure to mutagens. Lymphocytes are gold standard cells for cytogenetic analyses. Although commercially available cell lines may be used, lymphocytes are human primary cells that are easy to obtain and can be stimulated by mitogens such as phytohemagglutinin (PHA) (Johannes and Obe, 2013; OECD, 2014). This study was performed according to the principles of the local Ethics Committee (Instituto de Ciências da Saúde of Universidade Federal do Pará); written informed consent was obtained from participants prior to the study. Blood lymphocytes were isolated using a procedure described by Fenech (2000). The cells were seeded in Roswell Park Memorial Institute (RPMI) 1640 medium (Cultilab, Campinas, SP, Brazil) supplemented with $20 \%$ fetal bovine serum (Cultilab), 4\% PHA A (a specific mitogen for T lymphocytes; GibcoInvitrogen, Carlsbad, CA, USA), $0.05 \mathrm{mg} / \mathrm{mL}$ gentamicin sulfate (Cultilab) and $0.002 \mathrm{mg} / \mathrm{mL}$ amphotericin $\mathrm{B}$. Cells were cultured at $37^{\circ} \mathrm{C}$ in an incubator containing $5 \% \mathrm{CO}_{2}$.

\section{Cell viability}

Cell viability was assessed using the methylthiazole tetrazolium (MTT) assay. Lymphocytes were grown on 96-well culture plates at a concentration of $0.5 \times 10^{6}$ cells/ well and incubated for $24 \mathrm{~h}$. After the initial period of incubation, the cells were treated with different concentrations ( $\mathrm{v} / \mathrm{v})$ of tucupi $(1 ; 2 ; 4 ; 8 ; 16$ and $32 \%)$. The cells were incubated again for $24 \mathrm{~h}$, and subsequently incubated with $100 \mu \mathrm{L}$ MTT $(5000 \mu \mathrm{g} / \mathrm{mL})$ for $3 \mathrm{~h}$. Subsequently, the MTT was removed, and the cells were incubated with $100 \mu \mathrm{L}$ dimethyl sulfoxide (DMSO) (Sigma-Aldrich, St. Louis, MO, USA) for $1 \mathrm{~h}$ to dissolve the formazan obtained during the process. Afterward, the formazan diluted in DMSO was measured by spectrophotometry $(\lambda$ $=562 \mathrm{~nm}$ ) (Valadares et al., 2007). Cell survival was calculated as the absorbance percentage compared to that of the control.

\section{Comet assay (alkaline version)}

The comet assay was performed by growing cells at a concentration of $1 \times 10^{6}$ cells $/ \mathrm{mL}$; for $20 \mathrm{~h}$. The cultures were treated with different concentrations of tucupi $(2,4$ and $8 \%)$. Doxorubicin $(0.02 \mu \mathrm{g} / \mathrm{mL})$ was used as a positive control. After $3 \mathrm{~h}$ of treatment, the cells were centrifuged and $15 \mu \mathrm{L}$ cell suspension was homogenized with $300 \mathrm{~mL}$ lowmelting-point agarose $(0.8 \%)$, spread onto microscope slides precoated with a normal melting point agarose $(1.5 \%)$, and covered with a coverslip $(24 \times 60 \mathrm{~mm})$. After $5 \mathrm{~min}$ at $4^{\circ} \mathrm{C}$, the

Genetics and Molecular Research 15 (4): gmr.15048825 
coverslip was removed and the slides were immersed in cold lysis solution $(2.5 \mathrm{M} \mathrm{NaCl}$; $100 \mathrm{mM}$ EDTA, $10 \mathrm{mM}$ Tris, $10 \%$ DMSO and $1 \%$ Triton-X, $\mathrm{pH}=10$ ) for $72 \mathrm{~h}$. The cells were lysed, and the slides were placed in an electrophoresis chamber and covered with freshly made electrophoresis buffer $(300 \mathrm{mM} \mathrm{NaOH} ; 1 \mathrm{mM}$ EDTA, $\mathrm{pH}>13)$. The electrophoresis program was run for $25 \mathrm{~min}(34 \mathrm{~V}$ and $300 \mathrm{~mA})$. Afterwards, the slides were neutralized by submersion in distilled water $\left(4^{\circ} \mathrm{C}\right)$ for $5 \mathrm{~min}$ and fixed in $100 \%$ ethanol for $3 \mathrm{~min}$. The slides were stained with ethidium bromide $(20 \mu \mathrm{g} / \mathrm{mL})$ immediately before the analyses. The slides were prepared in duplicate, and 100 cells were screened per sample (50 cells from each slide) using a fluorescent microscope (Olympus BX41; Olympus, Tokyo, Japan) at 40X magnification. The damage index was visually determined based on the size and intensity of the tail of the comet. The following five categories ( $0-4)$ were used: class 0 (no damage), class 1 (little damage with a tail length shorter than the diameter of the nucleus), class 2 (medium damage with a tail length one or two times the diameter of the nucleus), class 3 (significant damage with a tail length one or two times the diameter of the nucleus), and class 4 (significant damage with a tail length greater than three times the diameter of the nucleus).

\section{Evaluation of apoptosis and necrosis using differential fluorescent staining with ethidium bromide/acridine orange}

This parameter was evaluated, by seeding $1 \times 10^{6}$ lymphocytes on three 12-well culture plates, containing $1 \mathrm{~mL}$ complete RPMI medium in each well. After $24 \mathrm{~h}$, the cells were treated with different concentrations (v/v) of tucupi (4, 8 and $16 \%)$. Doxorubicin $(0.2 \mu \mathrm{g} / \mathrm{mL})$ was used as the positive control. Analyses were performed after 24 and $48 \mathrm{~h}$ of treatment. Aliquots of the cell suspension $(1 \mathrm{~mL})$ were centrifuged at $1000 \mathrm{rpm}$ for 5 minutes and the pellet was homogenized with $25 \mu \mathrm{L}$ medium. Subsequently, a 1-mL solution of orange acridine ethidium bromide $(100 \mu \mathrm{g} / \mathrm{mL})$ was added and the solution was analyzed using the Olympus BX41, using fluorescein isothiocyanate filter (Montenegro et al., 2007). Three hundred cells were analyzed for each treatment group. The cell fields were randomly chosen and counted by a single person. Viable normal cells excluded ethidium bromide and showed round bright green nuclei with an intact structure. Necrotic cells had round red nuclei but no nuclear condensation. Apoptotic cells had a non-uniform pattern of staining where nuances of green and yellow were found in the same cell, with highly condensed (picnotic) or fragmented nuclei (Alcântara et al., 2013).

\section{Statistical analysis}

For parametric data sets, statistical analysis was performed using analysis of variance (ANOVA), followed by the Tukey test. For non-parametric data sets, the analysis was performed using the Kruskal Wallis test. The BIOESTAT 5.0 software (Ayres et al., 2007) was used to perform statistical analyses. P values $<0.05$ were considered statistically significant.

\section{RESULTS}

\section{Cell viability}

Cells treated with $8 \%$ tucupi (and higher concentrations) for $24 \mathrm{~h}$ showed a considerable decrease in viability (Figure 1). This decrease was statistically significant $(\mathrm{P}<0.05)$ in cells

Genetics and Molecular Research 15 (4): gmr.15048825 
treated with 16 and $32 \%$ tucupi compared to that seen in the control. The percentage viability of cells treated with $1,2,4,8,16$, and $32 \%$ tucupi were $109.7,110,109.3,76.4,50.02$, and $7.9 \%$ respectively. Tucupi concentrations ensuring a cell viability $\geq 50 \%$ were chosen for further assays, in conformance with the upper limit toxicity of $55 \pm 5 \%$ in in vitro cytogenetic tests recommended by Galloway et al. (2011).

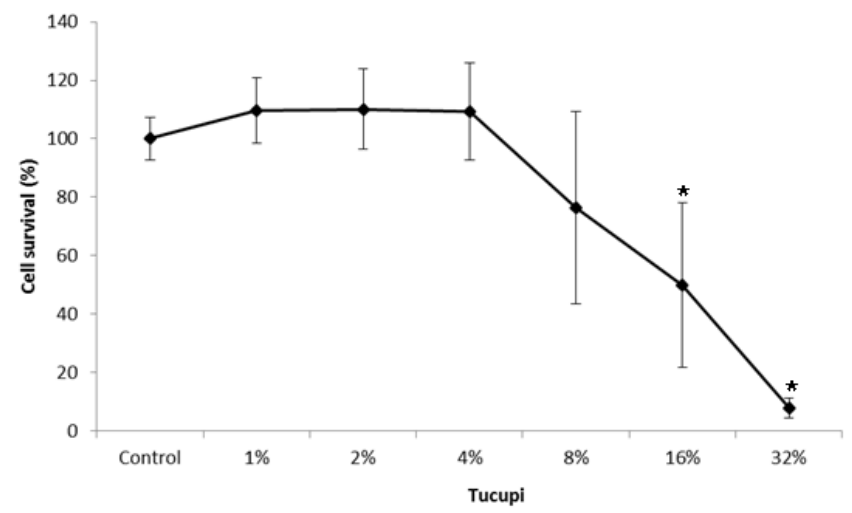

Figure 1. Percentages of cell survival in cultured lymphocytes observed after treatment with Tucupi for 24 h. $* \mathrm{P}<$ 0.05 (Kruskal-Wallis) compared to the control. All values are the mean of six experiments.

\section{Comet assay (alkaline version)}

The genotoxic effect of tucupi was evaluated by the comet assay. Treatment with tucupi was shown to induce an increase in the rate of DNA damage; however, this increase was not statistically significant for any of the tested concentrations (Figure 2). The average rates of damage observed in 100 cells were $1.88,1.94$, and 2.17, when treated with 2,4 , and $8 \%$ tucupi, respectively. Doxorubicin treatment induced a significant increase $(\mathrm{P}<0.05)$ in the damage index (2.82) compared to that in the negative control (1.50).

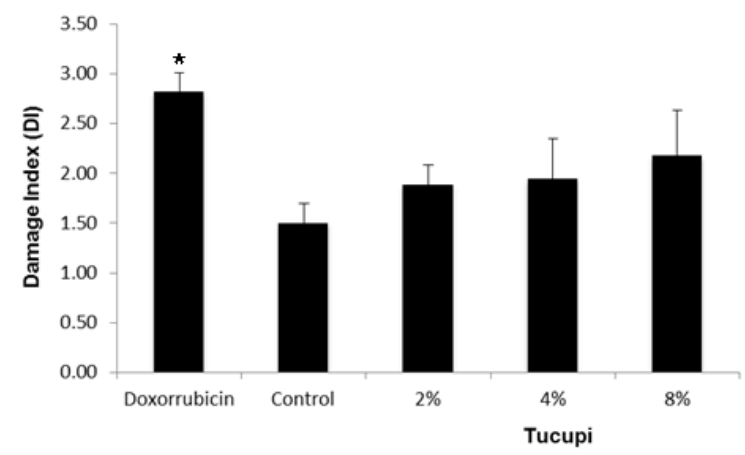

Figure 2. Index damage observed in lymphocyte culture after treatment with Tucupi. $* \mathrm{P}<0.05$ compared to the control. The data were analyzed by ANOVA with Tukey post-hoc test. All values represent the mean of three experiments.

Genetics and Molecular Research 15 (4): gmr.15048825 


\section{Evaluation of apoptosis and necrosis using ethidium bromide/acridine orange differential fluorescent staining}

The cell death-inducing effect of tucupi was analyzed after 24 and $48 \mathrm{~h}$; the $16 \%$ (concentration) tucupi extract induced significant cell death $(45.3 \%$; $\mathrm{P}<0.05)$ by necrosis after $48 \mathrm{~h}$ compared to the negative control (18.1\%) (Figure 3).

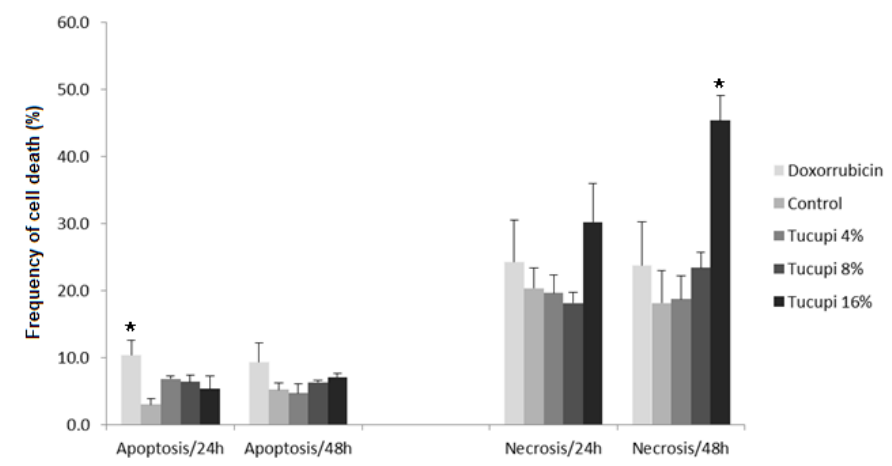

Figure 3. Induction of cell death observed in culture of human lymphocytes after treatment with Tucupi for 24 to 48 h. $* \mathrm{P}<0.05$ compared to the control. Data were analyzed by ANOVA with Tukey post-hoc test. All values represent the mean of three independent experiments.

The induction of apoptosis by tucupi was not statistically significant in any of the concentrations or harvest times, compared to the negative control. However, treatment with doxorubicin $(0.2 \mathrm{mg} / \mathrm{mL})$ induced significant apoptosis $(10.4 \%)(\mathrm{P}<0.05)$ compared to the negative control (3.0\%) after $24 \mathrm{~h}$ treatment.

\section{DISCUSSION}

The results of this study demonstrated that tucupi, the boiled juice of $M$. esculenta roots, exerts significant cytotoxic effects on cultured human lymphocytes, without, showing any genotoxic effects. Studies on the cytotoxicity and genotoxicity of tucupi are nonexistent. Some studies have been performed on extracts of cassava, but not as tucupi. For example, Olorunfemi et al. (2011) investigated the genotoxic effects of effluents from the processing of cassava roots, using the Allium cepa test. A significant increase in chromosomal aberrations, and decrease in mitotic index (both dose-dependent effects) was observed at all concentrations According to these authors, the observed genotoxic effects can be attributed the presence of heavy metals and cyanide in the tested effluents.

Cytotoxic and mutagenic effects of tea prepared from the leaves of another species of cassava (Manihot glaziovii) were evaluated by Melo et al. (2009) using the micronucleus test in rodent bone marrow. The authors reported that the tea had antimutagenic (in combination with cyclophosphamide) and cytotoxic effects on the rodent bone marrow cells. A reduced mutagenic effect was also observed; the cytotoxic effects were attributed to hydrocyanic acid.

The cytotoxic effects (induction of necrosis) observed in this study may also be because of hydrocyanic acid, which remains in the juice even after boiling (Chisté et al., 2007; Rosário and Oliveira, 2010). Chisté et al. (2007), who, studied the physicochemical properties 
of tucupi, reported the low $\mathrm{pH}$ of this extract (3.00 - 4.35), classifying this juice as a food of high acidity. According to these authors, acidic $\mathrm{pH}$, or a $\mathrm{pH}$ close to an acidic range, favors the production of $\mathrm{HCN}$ from linamarin, as the final stage of $\mathrm{HCN}$ production may be mediated by hydroxynitrile lyase, which acts in a $\mathrm{pH}$ range of 3.5-6.0, or may occur spontaneously when the $\mathrm{pH}$ is greater than 4.0. The $\mathrm{pH}$ of the various concentrations of tucupi was analyzed in this study. The pH of tucupi used in this study (5.2) is in the range reported by Chisté et al. (2007), and therefore favors the production of $\mathrm{HCN}$. The $\mathrm{pH}$ of the chosen concentrations of tucupi used in the cytotoxicity and genotoxicity tests (2 to 16\%) remained between 7.40 and 6.27 , not varying much from the neutral $\mathrm{pH}$ of the medium itself. The cytotoxic effects observed could be attributed to the possible presence of $\mathrm{HCN}$ in tucupi, and not its acidity.

Tucupi is an acidic source of nourishment (Chisté et al., 2007); in the conditions of our study, tucupi was show to induce necrosis in human lymphocytes. It is possible that the frequent consumption of tucupi may expose cells of the gastrointestinal tract to the same effects observed in this study. In fact, irritants such as alcohol, alkalis, and acids may induce necrosis that, in turn, is related to chemical esophagitis (Abbas et al., 2010). Finally, based on the results of the comet assay, further experiments using an exogenous source of metabolic activation would be required to confirm our negative results.

\section{Conflicts of interest}

The authors declare no conflict of interest

\section{ACKNOWLEDGMENTS}

L. A. Cunha was sponsored by a Masters fellowships from CAPES.

\section{REFERENCES}

Abbas AK, Fausto N and Kumar V (2010). Robins \& Contam - Bases Patologicas das Doenças. Elsevier, Rio de Janeiro. Alcântara DDFA, Ribeiro HF, Cardoso PC, Araújo TM, et al. (2013). In vitro evaluation of the cytotoxic and genotoxic effects of artemether, an antimalarial drug, in a gastric cancer cell line (PG100). J. Appl. Toxicol. 33: 151-156. http:// dx.doi.org/10.1002/jat.1734

Ayres M, Ayres MJ, Ayres DM and Dos Santos AS (2007). Bioestat 5.0: aplicações estatísticas nas áreas das ciências biológicas e médicas. Belém Pará.

Chisté RC, Cohen KO and Oliveira SS (2007). Estudo das propriedades físico-químicas do Tucupi. Cienc. Tecnol. Aliment. Campinas 27: 437-440. http://dx.doi.org/10.1590/S0101-20612007000300002

FAO (1995). Plant production and protection papers available. http://www.fao.org/documents/show. Accessed on November 17, 2010.

Fenech M (2000). The in vitro micronucleus technique. Mutat. Res. 455: 81-95. http://dx.doi.org/10.1016/S0027$\underline{5107(00) 00065-8}$

Ferreira CM (2004). Análises complementares obtidas a partir de testes de toxicidade aquática. In: Sanidade de organismos aquáticos (Rizani-Paiva MJT, Takemoto RM, Lizama MAP, Eds.). Livraria Varela Editora, São Paulo, 273-284.

Galloway S, Lorge E, Aardema MJ, Eastmond D, et al. (2011). Workshop summary: Top concentration for in vitro mammalian cell genotoxicity assays; and report from working group on toxicity measures and top concentration for in vitro cytogenetics assays (chromosome aberrations and micronucleus). Mutat. Res. 723: 77-83. http://dx.doi. org/10.1016/j.mrgentox.2011.01.003

Gomes PTC and Nassar NMA (2013). Cassava interspecific hybrids with increased protein content and improved amino acid profiles. 12: 1214-1222.

Idibie CA, Davids H and Iyuke SE (2007). Cytotoxicity of purified cassava linamarin to a selected cancer cell lines. Bioprocess Biosyst. Eng. 30: 261-269.http://dx.doi.org/10.1007/s00449-007-0122-3

Genetics and Molecular Research 15 (4): gmr.15048825 
Johannes C and Obe G (2013). Chromosomal aberration test in human lymphocytes. Methods Mol. Biol. 1044: 165-178. http://dx.doi.org/10.1007/978-1-62703-529-3_8

Li K, Zhu W, Zeng K, Zhang Z, et al. (2010). Proteome characterization of cassava (Manihot esculenta Crantz) somatic embryos, plantlets and tuberous roots. Proteome Sci. 8: 10. http://dx.doi.org/10.1186/1477-5956-8-10

Magalhães CP, Xavier-Filho J and Campos FAP (2000). Biochemical basis of the toxicity of manipueira (liquid extract of cassava roots) to nematodes and insects. Phytochem. Anal. 11: 57-60. http://dx.doi.org/10.1002/(SICI)10991565(200001/02)11:1<57::AID-PCA489>3.0.CO;2-E

Melo AJM, Almeida-Neto JX, Medeiros FPM, Silva JC, et al. (2009). Avaliação dos efeitos mutagênicos e citotóxicos da maniçoba (Manihot glaziovii muell arg), através do teste de micronúcleos em medula óssea de roedores in vivo. Rev. Biol. Farm. 3.

Montenegro RC, de Vasconcellos MC, Silva Bezerra F, Andrade-Neto M, et al. (2007). Pisosterol induces monocytic differentiation in HL-60 cells. Toxicol. In Vitro 21: 795-800. http://dx.doi.org/10.1016/j.tiv.2007.01.018

Olorunfemi DI, Okoloko GE, Bakare AA and Akimboro A (2011). Cytotoxic and genotoxic effects of cassava effluents using the Allium cepa assay. Res. J. Mutagen 1: 1-9. http://dx.doi.org/10.3923/rjmutag.2011.1.9

OECD (2014). Guideline for the testing of chemicals. In vitro mammalian chromosomal aberration test. TG 473. http:// www.oecd-ilibrary.org/docserver/download/9714531e.pdf?expires=1465216711\&id=id\&accname=guest\&checksu $\mathrm{m}=18 \mathrm{E} 03 \mathrm{~F} 4977023 \mathrm{D} 114 \mathrm{~B} 838603 \mathrm{D} 44 \mathrm{D} 9 \mathrm{FB} 0$. Accessed 22 May, 2016.

Ponte JJ (1999). Cartilha da manipueira - Uso do composto como insumo agrícola. Fortaleza, CE.

Resende ALS, Mattos IE and Koifman S (2006). Dieta e câncer gástrico: aspectos históricos associados ao padrão de consumo alimentar no Estado do Pará. Ver. Nutr. Campinas 19: 511-519.

Rosário DO and Oliveira J (2010). Levantamento das espécies vegetais cultivadas em roçados na comunidade de Vila da Penha - Maracanã/PA. Museu Paraense Emílio Goeldi.

Simão AS (2002). Diagnóstico da cadeia produtiva agroindustrial da mandioca - Mato Grosso. Cuiabá: SEBRAE, UNIVAG; Viçosa: Universidade Federal de Viçosa.

Valadares MC, Castro NC and Cunha LC (2007). Synadenium umbellatum: citotoxicidade e danos ao DNA de células da medula óssea de camundongos. Ver. Bras. Cienc. Farm. 43: 4.

Genetics and Molecular Research 15 (4): gmr.15048825 